\title{
Activity of total alkaline phosphatase in water of the Barlinek Lake of the during stagnation time of 2008
}

\section{Aktywność ogólnej fosfatazy zasadowej w wodzie jeziora Barlineckiego w okresie stagnacji letniej w 2008 roku}

\author{
Piotr Daniszewski \\ Katedra Chemii i Ochrony Środowiska Wodnego \\ Wydział Biologii \\ Uniwersytet Szczeciński, \\ ul. Felczaka 3C, 71-412 Szczecin, Poland \\ E-mail address: daniszewski@univ.szczecin.pl
}

\begin{abstract}
To estimate differentiation of activity of total alkaline phosphatase in water of the Barlinek Lake, of the during stagnation time of 2008. Studies upon water revealed that, among the zones analyzed, upper sublittoral layer was characterized by the highest phosphatase activity. From the analysis of seasonal oscillations it follows that activity maximum for alkaline phosphatase, both in water, occurred July 2008.
\end{abstract}

Keywords:

total alkaline phosphatase activity; phosphorus; water; Barlinek Lake; summer stagnation

\section{STRESZCZENIE}

Badaniami objęto wodę jeziora Barlineckiego. Próbki do badań pobierano w okresie od kwietnia do października 2008 roku. Badania dotyczące wody wykazały, że spośród analizowanych stref najwyższą aktywność fosfatazy zasadowej posiadała górna warstwa sublitoralu. $\mathrm{Z}$ dokonanej analizy wahań w okresie stagnacji letniej wynika, że maksimum aktywności ogólnej fosfatazy zasadowej w wodzie występowała w badanym jeziorze w lipcu 2008 roku.

\section{Slowa kluczowe}

aktywność ogólnej fosfatazy zasadowej, fosfor, woda, jezioro Barlineckie, stagnacja letnia 


\section{WPROWADZENIE}

Najbardziej przyswajalną biologiczną formą fosforu w zbiornikach wodnych, są jony ortofosforanowe. Jony te powstają $\mathrm{w}$ reakcjach hydrolizy nierozpuszczalnych form fosforu [Siuda W., 2001; Koc A., Skwierawski A, 2004].

Poziom aktywności alkalicznej fosfatazy (APA) ma istotny wpływ na procesy chemiczne i biologiczne jakie zachodzą w środowisku wodnym [Berman T. 1970; Smith R.E.H., Kalff J., 1981; Chróst R.J. i in.. 1984; Siuda W. 1984; Jansson M., i in. 1988]. APA jest wskaźnikiem, który mówi nam o stopniu ograniczenia rozwoju biomasy w danym zbiorniku wodnym [Smith R.E.H., Kalff J., 1981; Siuda W. 1984; Forsberg 1993].

Jak wynika $\mathrm{z}$ dokonanego przeglądu literatury, jak dotąd nie prowadzono szczegółowych badań dotyczących stanu jakości wód jeziora Barlineckiego. Celem badań w niniejszej pracy było prześledzenie w okresie stagnacji letniej (lipiec i sierpień) 2008 roku poziomu oraz dynamiki zmian w wodach jeziora Barlineckiego aktywności ogólnej fosfatazy zasadowej [1-10].

\section{CZĘŚĆ DOŚWIADCZALNA}

Badania przeprowadzono na jeziorze Barlineckim, które zajmuje powierzchnię 259,1 ha, posiada trzy dopływy i jeden odpływ. Otoczone jest morenowymi wzgórzami, w większości porośniętymi buczynami. Fragment brzegu zachodniego badanego jeziora przylega do łąk połączonych z polami uprawnymi. Północna i północno-wschodnia część jeziora graniczy z zabudowaniami miasta Barlinek (Marcinkiewicz W. 1963). Podstawowe dane morfometryczno-zlewniowe badanego jeziora przedstawiono w tabeli nr 1. Współrzędne geograficzne stanowisk pomiarowych rozmieszczonych na jeziorze Barlineckim:

Stanowisko nr 1 - N: $52^{\circ} 58^{\prime} 19,31^{\prime \prime}$ E: $15^{\circ} 11^{\prime} 45,69^{\prime \prime}$

Stanowisko nr 2 - N: $52^{\circ} 58^{\prime} 45,74^{\prime \prime}$ E: $15^{\circ} 12^{\prime} 27,14^{\prime \prime}$

Stanowisko nr 3 - N: $52^{\circ} 59^{\prime} 05,08^{\prime \prime}$ E: $15^{\circ} 13^{\prime} 07,81^{\prime \prime}$

Stanowisko nr 4 - N: $52^{\circ} 59^{\prime} 27,55^{\prime \prime}$ E: $15^{\circ} 13^{\prime} 12,20^{\prime \prime}$

Tabela 1. Dane morfometryczno-zlewniowe jeziora BarlineckiegO

\begin{tabular}{|c|c|c|c|c|c|c|c|}
\hline \multirow[t]{3}{*}{ Lp. } & \multirow[t]{3}{*}{$\begin{array}{c}\text { Nazwa } \\
\text { jeziora } \\
\text { Lake } \\
\text { name }\end{array}$} & $\begin{array}{c}\text { Szerokość } \\
\text { geograficzna } \\
\text { Latitude }\end{array}$ & $\begin{array}{c}\text { Dlugość } \\
\text { geograficzna } \\
\text { Longitude }\end{array}$ & $\begin{array}{c}\text { Wysokość } \\
\text { n.p.m. } \\
\text { Height } \\
\text { above see } \\
\text { level } \\
\end{array}$ & $\begin{array}{c}\text { Głębokość } \\
\text { maksymalna } \\
\text { Maximal } \\
\text { depth }\end{array}$ & $\begin{array}{c}\text { Głębokość } \\
\text { średnia } \\
\text { Average } \\
\text { depth }\end{array}$ & $\begin{array}{l}\text { Powierzchnia } \\
\text { zw. wody } \\
\text { Water } \\
\text { surface area }\end{array}$ \\
\hline & & $\mathrm{N}$ & $\mathrm{E}$ & $\mathrm{m}$ & $\mathrm{m}$ & $\mathrm{M}$ & ha \\
\hline & & $52^{\circ} 58,9^{\prime}$ & $15^{\circ} 12,9^{\prime}$ & 57,0 & 18,0 & 7,1 & 259,1 \\
\hline \multirow[t]{3}{*}{1.} & \multirow[t]{3}{*}{$\begin{array}{l}\text { Barlineckie } \\
\text { (Barlińskie) }\end{array}$} & $\begin{array}{c}\text { Powierzchnia } \\
\text { wysp } \\
\text { Island area }\end{array}$ & $\begin{array}{l}\text { Objętość } \\
\text { Volume }\end{array}$ & $\begin{array}{c}\text { Długość } \\
\text { maksymal } \\
\text { na } \\
\text { Maximal } \\
\text { length }\end{array}$ & $\begin{array}{c}\text { Szerokość } \\
\text { maksymalna } \\
\text { Maximal } \\
\text { width }\end{array}$ & $\begin{array}{c}\text { Linia } \\
\text { brzegowa } \\
\text { misy } \\
\text { jeziora } \\
\text { Coastline } \\
\text { of lake's } \\
\text { basin } \\
\end{array}$ & $\begin{array}{c}\text { Linia } \\
\text { brzegowa } \\
\text { wysp } \\
\text { Islands } \\
\text { coastline }\end{array}$ \\
\hline & & ha & $10^{3} \mathrm{~m}^{3}$ & $\mathrm{~m}$ & $\mathrm{~m}$ & $\mathrm{M}$ & $\mathrm{m}$ \\
\hline & & 3,7 & 18579,8 & 3770 & 2150 & 10450 & 1550 \\
\hline
\end{tabular}


Do badań próbki wody litoralnej i sublitoralnej pobierano za pomocą aparatu Ruttnera o pojemności $2 \mathrm{dm}^{3}$. Dalsze postępowanie $\mathrm{z}$ pobranymi próbkami wody było prowadzone zgodne z PN/C-04632.03 - Ogólne zasady pobierania próbek do badań fizycznych, chemicznych i biologicznych. Technika pobierania próbek. i PN/C-04632.04 - Ogólne zasady pobierania próbek do badań fizycznych, chemicznych i biologicznych. Utrwalanie i przechowywanie próbek.

Wodę przez dobę przechowywano $\mathrm{w}$ temperaturze $4^{\circ} \mathrm{C}$. Po okresie tym określano w wodzie aktywność ogólnej fosfatazy zasadowej metodą Jonesa [Jones J.G. 1972]. Metoda Jonesa oznaczania aktywności ogólnej fosfatazy zasadowej polega na wykryciu barwnego pnitrofenolu powstałego $\mathrm{z}$ fosforanu $\mathrm{p}$-nitrofenolu rozpuszczonego w buforze $(0,1 \mathrm{M}$ Tris- $\mathrm{HCl}$ o pH 8,5) [Jones J.G. 1972]. Badania prowadzone były w okresie w 2008 roku w miesiącu lipcu i sierpniu. Analizy wykonywano raz w miesiącu w trzech powtórzeniach. Przedstawione w pracy wyniki stanowią średnią z tych powtórzeń.

\section{DYSKUSJA WYNIKÓW}

Wyniki badań aktywności ogólnej fosfatazy zasadowej w wodach jeziora Barlineckiego zostały przedstawione w tabeli 2 .

Tabela 2. Aktywność ogólnej fosfatazy zasadowej w wodzie $\left(\mathrm{nmol} \mathrm{PO}_{4} \cdot \mathrm{dm}^{-3} \cdot \mathrm{h}^{-1}\right)$

\begin{tabular}{|c|c|c|c|}
\hline Lp. & Terminy badań & Litoral & Sublitoral \\
\cline { 3 - 4 } & & $\mathbf{1 ~} \mathbf{~}$ & $\mathbf{4} \mathbf{~ m}$ \\
\hline 1. & $\mathbf{2 4 . 0 7 . 2 0 0 8}$ & 637,6 & 510,4 \\
\hline 2. & $\mathbf{2 0 . 0 8 . 2 0 0 8}$ & 476,3 & 472,1 \\
\hline 3. & Średnia & $\mathbf{5 5 6 , 9 5}$ & $\mathbf{4 9 1 , 2 5}$ \\
\hline
\end{tabular}

Powyższe wyniki wskazują, że aktywność ogólnej fosfatazy zasadowej w wodzie jeziora Barlineckiego kształtowała się na najwyższym poziomie w okresie lipca, zarówno $\mathrm{w}$ litoralu jak i sublitoralu. W litoralu poziom badanego wskaźnika wynosił $637,6 \mathrm{nmol} \mathrm{PO}_{4} \cdot \mathrm{dm}^{-}$ ${ }^{3} \cdot \mathrm{h}^{-1}$, a w sublitoralu od $510,4 \mathrm{nmol} \mathrm{PO}_{4} \cdot \mathrm{dm}^{-3} \cdot \mathrm{h}^{-1}$. Podczas prowadzonych badań aktywności ogólnej fosfatazy zasadowej, wody ocenianego jeziora, nie podlegała istotnym wahaniom $\mathrm{w}$ okresie lipiec - sierpień 2008 roku. Poszerzone badania wód jeziora Barlineckiego w 2008 roku w zakresie określenia zmian aktywności ogólnej fosfatazy zasadowej oraz wartości 19 wskaźników, które określają jakość wód, zostały przedstawione w pracach Daniszewski.

\section{WNIOSKI}

1. Aktywność ogólnej fosfatazy zasadowej w wodzie jeziora Barlineckiego była najwyższa w warstwie sublitoralu w okresie stagnacji letniej w miesiącu lipcu.

2. Aktywność ogólnej fosfatazy zasadowej w wodzie badanego jeziora nie podlegała istotnym wahaniom w okresie stagnacji letniej. 


\section{LITERATURA}

[1] Barik S.K., Purushothaman C.S., Mohanty A.N., Aquaculture Research, 32 (2001) 819-832

[2] Berman T.. Alkaline phosphatases and phosphorus availability in lake Kinneret. Limnol. and Oceanogr.,XV (5), (1970) 663-674.

[3] Chróst R.J., Siuda W., Halemejko G.Z. 1984.. Arch. Hydrobiol. Suppl., 70, 1 (1984) $1-32$.

[4] Daniszewski P., International Letters of Chemistry, Physics and Astronomy 1 (2012) 6-12.

[5] Daniszewski P., International Letters of Chemistry, Physics and Astronomy 1 (2012) 13-16.

[6] Koc A., Skwierawski A, Fosfor w wodach obszarów rolniczych. Prace Naukowe Akademii Ekonomicznej we Wrocławiu, (2004) 1017, 168

[7] Marcinkiewicz W., Barlineckie Jezioro. Wyd. Instytut Rybactwa Śródlądowego, Olsztyn 1963

[8] Siuda W., Polish Archives of Hydrobiology, 31 (1984) 207-233.

[9] Siuda W., Post. Mikrobiol., 40, 2, (2001) 187-217.

[10] Smith R.E.H., Kalff J., Can. J. Fish Aquat Sci., 38 (1981) 1425.

\section{Polskie Normy}

PN/C-04632.03. Ogólne zasady pobierania próbek do badań fizycznych, chemicznych i biologicznych. Technika pobierania próbek.

PN/C-04632.04. Ogólne zasady pobierania próbek do badań fizycznych, chemicznych i biologicznych. Utrwalanie i przechowywanie próbek.

PN/C-06504. Przygotowanie roztworów buforowych. 